системи практичної підготовки студентів та періодично оновлювати їх, відповідно до вимог сучасного освітнього процесу; створювати систему ранньої адаптації випускників на первинних посадах, шляхом дозволу навчання студентів старших курсів за індивідуальним графіком, у зв'язку із працевлаштуванням за спеціальністю, та проведенням «Ярмарку кар’єри».

\title{
Література
}

1. Вербицкий А. А. Активное обучение в высшей школе : контекстный подход / Андрей Александрович Вербицький. - М. : Высш. шк., 1992. - 123 с. 2. Лист МОН 1/9-93 від 07.02.2009 р. «Про практичну підготовку студентів» / І. О. Вакарчук. - К, 2009. - С. 1. 3. Освітньо-професійна програма підготовки бакалавра (в частині розподілу навчального часу за циклами підготовки, переліку та обсягу нормативних дисциплін галузі знань «0101Освіта», напрямку підготовки 6.010102 «Початкова освіта») / керівн. розроб. Бондар В. І. - К. : НПУ ім. М. П. Драгоманова, 2009. 4. Педагогіка вищої школи : [навч. посіб.] / 3. Н. Курлянд, П. І. Хмелюк, А. В. Семенова та ін., / за ред. 3. Н. Курлянд. - 3-тє вид., перероб. і доп. - К. : Знання, 2007. - 495 с. 5. Положення «Про проведення практик студентів»: за станом на 28 вересня 2009 р. / підгот. Т. А. Тернавська. Кіровоград : ПВНЗ «СПІ Педагогічна академія», 2009. - 14 с.

УДК 371.13:316.647.5

I. C. Тишик, acniрант,

Кіровоградський державний педагогічний університет імені Волдимира Винниченка

\section{ДО ВИЗНАЧЕННЯ ПОНЯТТЯ «МІЖЕТНІЧНА ТОЛЕРАНТНІСТЬ» У ПРОЦЕСІ ПІДГОТОВКИ МАЙБУТНІХ ВИКЛАДАЧІВ}

Тишик I. С. До визначення поняття «міжетнічна толерантність» у процесі підготовки майбутніх викладачів.

У статті представлено аналіз понять «толерантність» та «міжетнічна толерантність», доведено важливість формування міжетнічної толерантності як одного 3 визначальних чинників професійного становлення майбутніх викладачів.

Ключові слова: толерантність, міжетнічна толерантність, міжетнічна взаємодія, особистість майбутнього викладача.

Тишик I. С. К определению понятия «этническая толерантность» в процессе підготовки будущих преподавателей.

В статье проанализировано значение таких понятий, как «толерантность» и «этническая толерантность», обосновывается важность формирования межэтнической толерантности как обязательного фактора профессионального становления будущего преподавателя.

Ключевые слова: толерантность, межэтническая толерантность, формирование личности будущего преподавателя.

Tyshyk I. S. To the definition of notion «interethnic tolerance» in the process of training of future teachers.

The article reveals theoretical analysis concepts «tolerance» and «ethnic tolerance». Based on the analysis of psycho-pedagogical literature discusses the importance of creating interethnic tolerance as one of the most important factors of professional development for future teachers.

Key words: tolerance, interethnic tolerance, interethnic interaction, the identity formation of future teacher.

Проблема побудови міжетнічних відносин є ознакою глобалізаційних процесів та соціокультурних реалій нашої держави. Незважаючи на те, що поняття «толерантність» і «міжетнічна толерантність» стали загальновживаними в галузі суспільних наук, вони й донині залишаються змістовно «розмитими». Входження України до Болонського процесу 
зумовлює активізацію міжетнічних контактів, тому формування толерантного ставлення до представників різних етносів стає актуальним завданням сучасної вищої освіти.

Згідно із 56 ст. Закону України «Про освіту», педагогічні та науково-педагогічні працівники зобов'язані «виховувати у дітей та молоді повагу до батьків, жінки, старших за віком, народних звичаїв, національних, історичних цінностей України, їі державного і соціального устрою ..., готувати учнів та студентів до свідомого життя в дусі взаєморозуміння, миру, злагоди між усіма народами, етнічними, національними, релігійними групами ...» [8].

Зміни, що відбулися в суспільстві протягом останнього десятиріччя, зумовили підвищення інтересу науковців до проблем підготовки викладачів ВНЗ. Означену проблему в Україні досліджують В. Гриньова, В. Кремень, В. Олійник. Процеси й умови формування толерантності у студентів ВНЗ досліджувала Є. Рибак. Наукові положення щодо проблеми виховання міжетнічної толерантності розроблені російськими науковцями (Н. Лебедєва, О. Луньова, Т. Стефаненко, Г. Солдатова).

Однак нині більшість наукових досліджень стосовно формування міжетнічної толерантності присвячено здебільшого роботі 3 дітьми шкільного віку. Проблема виховання міжетнічної толерантності в майбутніх викладачів розглядалася лише в контексті загальних вимог до сучасного викладача.

Метою статmі є теоретичний аналіз підходів науковців до тлумачення понять «толерантність» та «міжетнічна толерантність», визначення місця формування міжетнічної толерантності майбутніх викладачів.

Поняття толерантності формувалося протягом багатьох віків і продовжує формуватися нині. На сучасному етапі розвитку наукової думки толерантність є предметом вивчення багатьох соціогуманітарних наук. Термін тлумачиться по-різному - залежно від специфіки об'єкта дослідження окремої науки, проте, незважаючи на відмінність у змістовному наповненні, скрізь визначається як здібність індивіда терпимого ставлення до людей, процесів і явищ, відмінних від його особистих, і розуміння того, що світ різноманітний і не зводиться до індивідуального світосприйняття кожної людини [7, с. 31]. Існують культурно-історичні відмінності в підходах до визначення толерантності. Свропейські науковці (М. Байрам, М. Беннет, Д. Хорн) визначають толерантність як «підтримку» [4, c. 59]. Натомість трактування поняття толерантності вітчизняними науковцями зводиться до «терпимості» [4, с. 60]. Варто зазначити, що поняття толерантності є відносно новим для українських науковців. Це зумовлено тим, що наша країна протягом майже всього ХХ століття перебувала у складі Радянського Союзу і науковці з огляду на тогочасну державну ідеологію не мали змоги всебічно досліджувати зазначене поняття.

Науковці неодностайні у питанні виникнення терміну толерантність у світовій культурі, пов'язуючи його появу з підписанням Нантського едикту (1598р.), коли протестанти і католики знайшли компроміс між своїми конфесіями.

Важливим етапом в історії толерантності також вважають кромвельський період англійської історії (17 ст.). На той час серед різних пуританських сект, що входили до армії Кромвеля, були дві - індепенденти та левелери, які відстоювали інтереси свободи та терпіння. Згідно з їх поглядами, жодне з тверджень не може бути настільки непогрішним, щоб йому можна було принести в жертву інші переконання, які існують у суспільстві. В умовах релігійного плюралізму і релігійної толерантності Англія досягла миру та всезагальної атмосфери милосердя.

Епоха Відродження (18 ст.), яку часто наділяють духом толерантності, породила дуже небезпечний якобінський фанатизм раціоналістичного типу. Найвизначнішим представником толерантності в ті часи був Вольтер. Його вважають автором вислову: «Я не згоден $з$ тим, що ви говорите, але віддам своє життя, захищаючи ваше право висловити свою думку» [6, с. 13-25].

Одним із видів толерантності є міжетнічна толерантність. Нашу дослідницьку увагу привертає концептуалізація цього поняття. Передовсім застосовується в етнопедагогіці, 
етнології та етнопсихології. Науковці почали його активно використовувати лише наприкінці 80-х років XX століття.

В окремих випадках термін «етнічність» є синонімом «національності». Цим поняттям підкреслюється ідентичність людей, заснована на спільному походженні [14, с. 321]. Автори, які аналізують явище міжетнічної толерантності (Н. Ротар, В. Трощинський), не подають його конкретного визначення і зазвичай ототожнюють із поняттям етнічної толерантності. На нашу думку, термін міжетнічна толерантність $є$ коректнішим, тому що будь-яка толерантність виявляється у процесі взаємодії щонайменше двох суб'єктів, у цьому випадку - представників двох етносів.

Український дослідник М. Євтух подає таке визначення міжетнічної толерантності: «Міжетнічна толерантність - терпиме ставлення представників однієї етнічної спільноти до представників іншої спільноти, до відмінних культурних традицій, готовність до позитивної взаємодії з носіями різноманітних етнічностей» [9, с. 10]. Міжетнічна толерантність виявляється у вчинках і формується у сфері свідомості. Специфіка поняття «міжетнічна толерантність», на думку російського науковця В. Гурова, полягає в тому, що вона розуміється як вид толерантності, в основі якого - прийняття «іншого», зумовлене приналежністю до іншої етнічної групи, і якщо толерантність сприймається як риса особистості, то міжетнічна толерантність розуміється як комплекс установок по відношенню до іншої етнічної групи. Виходячи з цього, дослідник робить висновок, що толерантність як особистісна риса $є$ стабільнішою характеристикою, а міжетнічна толерантність / інтолерантність зумовлена як внутрішніми, так і зовнішніми факторами, $\mathrm{i}$ тому легше піддається змінам [15, с. 156-170].

«Декларація принципів толерантності», прийнята ЮНЕСКО у 1995р., формулює настановчі принципи міжетнічної толерантності: «повага і розуміння багатоманітності культур нашого світу», «обов'язок сприяти утвердженню прав людини, плюралізму (у т.ч. культурного) демократії і правопорядку» [5].

С. Баранов у статті «Етнічна толерантність» [1] виокремлює такі типи міжетнічної толерантності: активна толерантність (відкрита готовність до міжетнічного контакту); пасивна толерантність (нерегулярність міжетнічних контактів, схильність до спілкування з представниками своєї національності, за збереження позитивного ставлення до представників інших етнічних груп); толерантність вибіркова (міжетнічний контакт за якоюсь ознакою - мова, релігія, культурні особливості); толерантність примусова (міжетнічні контакти виникають під тиском обставин i мають виключно діловий характер); інтолерантність (категоричне небажання взаємодіяти 3 людьми іншої культури).

У публікації ми розглядаємо поняття толерантності, в першу чергу, як повагу, сприйняття і правильне розуміння багатого різноманіття культур світу та способів вияву людської індивідуальності. Міжетнічну толерантність визначатимемо як визнання того, що люди від природи відрізняються зовнішнім виглядом, становищем, мовою, цінностями й володіють правом зберігати індивідуальність, а також усвідомленням того, що погляди однієї людини не можуть бути нав'язані.

Сучасні умови розвитку суспільства висувають нові вимоги до підготовки педагога школи майбутнього. Науковці, досліджуючи проблему професійного становлення сучасного педагога у вищих навчальних закладах, наголошують на тому, що толерантність є одним із найважливіших чинників професійного становлення сучасного педагога, оскільки під час педагогічного процесу викладач має спілкуватися 3 різними категоріями населення, які відмінні мовою, культурою, конфесійною приналежністю, i при цьому враховувати їхні особистісні цінності. Отже. світова педагогіка у відповідь на вияв нових соціокультурних реалій (прагнення до етнічного самовизначення в умовах глобалізації) розробляє нові стратегії освіти, які грунтуються на теорії толерантності: мультикультурна освіта, міжкультурна освіта, педагогіка культури миру. 
Студент, який вступає до ВНЗ, продовжує розвиватися як особистість. Визначна роль у цьому належить викладачу ВН3, який безпосередньо впливає на розвиток особистості майбутнього професіонала. У зв'язку з цим досить гостро постає потреба розвитку культури толерантного ставлення, оскільки важко не погодитися 3 тим твердженням, що педагог, який не є носієм принципів міжетнічної толерантності в особистісному аспекті, не може виховувати толерантну людину, соціальне замовлення на яку продиктоване сучасними світовими інтеграційними процесами.

Викладачі разом зі студентами є основними суб'єктами вищої професійної освіти. Прийняті Генеральною конференцією ЮНЕСКО в 1997 році рекомендації щодо питання про статус викладацьких кадрів ВНЗ стверджують, що вищі навчальні заклади, їх співробітники та студенти мають активно розповсюджувати універсально визнані термінальні цінності: мир, справедливість, рівноправність, використовуючи при цьому власний інтелектуальний потенціал і моральний авторитет [3].

Педагогічна толерантність, а відтак і міжетнічна толерантність, містить когнітивний, емоційний та поведінковий компоненти.

Суть когнітивного компонента формування міжетнічної толерантності полягає в наданні інформації про толерантність, міжетнічні взаємини, різноманітність культур світу. Цей компонент формується завдяки змістовому навантаженню навчальних курсів. На нашу думку, з огляду на поліетнічність нашої держави виникла нагальна потреба введення курсу «Етнології» на всіх факультетах педагогічного вишу, а не лише на історичному, оскільки ця дисципліна покликана надати студентам системні знання про процеси етногенезу й антропогенезу, історичне багатоманіття культур, особливості етнічного самоусвідомлення, форми і способи міжетнічної комунікації, причини міжетнічних конфліктів і шляхи їх розв'язання.

Емоційне сприйняття студентами інформаційного матеріалу повинно супроводжуватися розкриттям краси традицій i культур різних народів, пошуком культурних порівнянь. Доцільно використовувати відеолекції, драматизацію етнографічних обрядів, рольові ігри, проведення корегувальних тренінгів тощо.

Поведінковий компонент формується вже безпосередньо під час спілкування 3 представниками інших етносів. Безсумнівно, проблема формування міжетнічної толерантності не розв'язується одним введенням етнології в навчальні плани всіх факультетів педагогічного ВНЗ, але це може значно покращити формування міжетнічної культури в майбутніх викладачів усіх спеціальностей.

3 огляду на все вищесказане можна зробити висновки.

У психолого-педагогічній і філософській літературі не існує чіткого визначення понять «толерантність» та «міжетнічна толерантність», але загалом вони розуміються у двох аспектах: як «терпимість» та «підтримка» до сприйняття представників різних етносів.

Формування міжетнічної толерантності $€$ одним із важливих аспектів підготовки майбутніх викладачів, оскільки свого часу К. Ушинський зазначав, що виховання особистості можливе лише особистістю, а відтак формування міжетнічної толерантності майбутнього викладача $є$ передумовою формування міжетнічної толерантності всього соціуму, що вкрай необхідне в умовах полікультурності нашої держави.

Однак варто констатувати, що цілеспрямованого навчання в окресленому напрямку педагогічних вишів не ведеться, а формування навичок міжетнічної взаємодії з різними учасниками навчального процесу відбувається стихійно. Тому потребує подальшого дослідження проблема готовності майбутнього викладача до окресленого феномену, пошуку шляхів формування міжетнічної толерантності майбутніх викладачів.

\section{Література}

1. Баранов С. Т. Этническая толерантность / С. Т. Баранов - [Електронний ресурс]. - Режим доступу: http://www.nestu/ru. 2. Бондырева С. К. Толерантность (введение в проблему) : Гучеб.метод.пособ.]. / С. К. Бондырева, Д. В. Колесов. - М. ; Воронеж : Изд-во Моск. психол.-соц. ин-та : МОДЭК, 2003. - 240 с. 3. Высшее образование в XXI веке (по материалам ЮНЕСКО) // 
Образование в документах. Информационный бюллетень. - 1999. - №5 (92). 4. Грива О. А. Толерантність як складова життєвої компетентності особистості / О.А. Грива // Науковий часопис Національного педагогічного університету ім. М.П.Драгоманова. - Серія 7: Релігієзнавство, культурологія, філософія. - 2005. - Вип. 6 (19). - С. 58-67. 5. Декларація принципів толерантності / [Електронний ресурс]. - Режим доступу: http://zakon2.rada.gov.ua/laws/ show/995_503 6. Довідник міжетнічної толерантності / упоряд. Н. Ю. Ротар; за ред. А. М. Круглашова. - Чернівці : Видавничий дім «Букрек», 2011. - 232 с. 7. Етносоціологія: терміни та поняття : [навч. посіб.]. - К. : Фенікс, 2003. - 234 с. 8. Закон України «Про освіту» / [Електронний ресурс]. - Режим доступу: Ошибка! Недопустимый объект гиперссылки.9. Міжетнічна інтеграція: постановка проблеми в українському контексті [Текст] : [навч. посіб.] / В. Б. Свтух, В. П. Трощинський, Л. О. Аза. - К. : ВПЦ «Київ. ун-т», 2003. - 58 с. 10. Кожухарь Г. С. Проблема толерантности в межличностном общении / Г.С. Кожухарь // Вопросы психологии. - 2006. - № 2. - С. 3 - 12. 11. Краткий психологический словарь / под ред. А. В. Петровского, М. Г. Ярошевского. - М. : Политиздат, 1985. - 431 с. 12. Толерантность в межкультурном диалоге. - М. : Институт этнологии и антропологии РАН, 2005. - 365 с. 13. Лебедева Н. М. Межкультурный диалог: проблемы этнокультурной компетентности / Н. М. Лебедева // Этнический фактор в многонациональном пограничном регионе. - Оренбург, 2007. - С. 6 - 29. 14. Словник іншомовних слів / за ред. О. С. Мельничука. - 2-е видання, випр. і доп. - К. : Головна редакція «Українська радянська енциклопедія» (УРЕ), 1985. - 966 с. 15. Формирование толерантной личности в полиэтнической образовательной бреде : [учебное пособие]. - М. : Педагогическое общество России, 2004. - 240 с.

УДК 378.147:54

E. В. Часова, кандидат хім. наук, доцент,

B. В. Івчук, кандидат біолог. наук, ст. викладач, ДВНЗ «Криворізький начіональний університет»

\section{ПЕРСПЕКТИВИ ХІМІЧНОЇ ОСВІТИ В УНІВЕРСИТЕТАХ ТЕХНІЧНОГО ПРОФІЛЮ}

Часова Е. В., Івчук В. В. Перспективи хімічної освіти в університетах технічного профілю.

У статті окреслено основні тенденції хімічної освіти в університетах технічного профілю. Висвітлено роль забезпечення якості вищої освіти як важливої умови інноваційного розвитку у професійно зорієнтованому навчанні.

Ключові слова: хімічна освіта, нехімічні спеціальності, технічні університети, форми навчального процесу, аксіологія.

Часова Э. В., Ивчук В. В. Перспективы химического образования в университетах технического профиля.

В статье приведены основные тенденции химического образования в университетах технического профиля. Показана роль обеспечения качества высшего образования как важное условие инновационного развития в профессионально ориентированном обучении.

Ключевые слова: химическое образование, нехимические специальности, технические университеты, формы учебного процесса, аксиология.

Chasova E. V., Ivchuk V. V. Perspectives of chemical education in universities of technical profile.

The article led the main trends of chemical education at the universities of technical profile. The role of quality assurance in higher education, as an essential condition for innovative development in the career-oriented education.

Key words: chemical education, non-chemical specialties, technical universities, the forms of the educational process, axiology.

Нині вітчизняна вища освіта стає все більш доступною. Вибір абітурієнта є однією 3 актуальних проблем. Головною перешкодою для багатьох абітурієнтів є те, що вища освіта може бути платною та зміни в характері взаємовідношень між професійними навчальними закладами і школами. Останнім часом окреслилася небажана тенденція 